\title{
滝用水車からの電力を利用したルビー単結晶の育成
}

\section{Flux Growth of Ruby Crystals by Use of Electric Power Generated by a Micro Hydro Turbine Set in a Waterfall}

\author{
○ 大石修治（信州大）纐纈·明（信州大）手嶋勝弥（信州大） \\ 正 飯尾昭一郎（信州大） 正 池田敏彦（信州大）
}

\begin{abstract}
Shuji OISHI, Shinshu University, 4-17-1, Wakasato, Nagano 380-8553
Akira KOUKETSU, Shinshu University, 4-17-1, Wakasato, Nagano 380-8553

Katsuya TESHIMA, Shinshu University, 4-17-1, Wakasato, Nagano 380-8553

Shouichiro IIO, Shinshu University, 4-17-1, Wakasato, Nagano 380-8553

Toshihiko IKEDA, Shinshu University, 4-17-1, Wakasato, Nagano 380-8553
\end{abstract}

Key Words: Ruby Crystal, Flux Growth, Electric Power, Micro Hydro Turbine, Waterfall

1. はじめに

宝石は，古来から多くの人々を魅了してきた．中でも，酸 化アルミニウム $\left(\mathrm{Al}_{2} \mathrm{O}_{3}\right.$, コランダム) に微量のクロム $(\mathrm{Cr})$ をドープしたルビー $\left(\mathrm{Al}_{2} \mathrm{O}_{3}: \mathrm{Cr}\right)$ は, 赤色宝石としてあまり にも有名である.ルビーをはじめとする酸化アルミニウム結

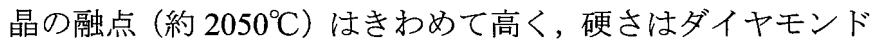
に次ぐ. 電気絶縁性や化学的安定性にも富み, 酸化アルミニ ウム結晶は，すぐれた機械材料（ボールベアリング，ナイフ エッジ，キャピラリーなど）になる.

昔から，ルビー単結晶を作る試みは数多くなされてきた。 工業的なルビ一製造には, 融液法に属するベルヌーイ法が多 用されている，円柱状のルビ一結晶が成長する，一方，溶液 法に属するフラックス法 (無機化合物などを溶媒とする結晶 育成法）は，融点よりもはるかに低い温度で結晶を育成でき る環境調和型技術である。この方法は，自形（結晶構造を反 映したフラットな結晶面で囲まれた形態) 結晶が成長する特 長ももっている.ルビー結晶を育成するフラックスには，従 来から鉛化合物 $\left(\mathrm{PbO}\right.$ や $\mathrm{PbF}_{2}$ など） や承晶石 $\left(\mathrm{Na}_{3} \mathrm{AlF}_{6}\right)$ が 多く使われてきた。これらのフラックスには，取り扱いや毒 性の問題点がある。最近，大石と手嶋らは酸化モリブデン $\left(\mathrm{MoO}_{3}\right)$ フラックス蒸発法により六方両錐形ルビー結晶を 成長させる技術を世界に先がけて開発した(1),(2),(3),(4)。酸化ナ トリウム $\left(\mathrm{Na}_{2} \mathrm{O}\right)$ などの塩基性酸化物をフラックス（酸性酸 化物）に添加して蒸発をコントロールすると, 結晶が大型化 することもわかった ${ }^{(5),(6)}$. フラックス法によるルビー結晶の 育成実験には，必ず電気炬を用い，電力を消費する.

近年, 水力エネルギーを使用した環境にやさしい発電が大 いに注目されている。池田らは，小型水車を開発し，小さな 川の流れを利用したマイク口水力発電に成功し(7)，その電力 の応用を展開している.

自然エネルギーから得た電力で，できる限り低い温度で高 品質ルビ一結晶を育成することは，省資源や省エネルギーの 観点からもきわめて重要である. 本研究の目的は, 滝用水車 で発電した電力を利用して電気炉を加熱し, 酸化モリブデン 系フラックス高温溶液からルビー単結晶を育成することで ある。

\section{2. 実験方法}

まず, 水車から得られる電力を利用してルビー単結晶を育 成するための条件（温度や調合物組成など）を探る予備実験 を実験室内で行った，続いて，予備実験での検討結果に基づ
いた条件を用い, 長野県小諸市相生町の松井川（川幅: 約 1.5 $\mathrm{m}$, 水位 : $5 \sim 10 \mathrm{~cm}$ ) の小さな滝の流れから得た電力でルビ 一結晶の育成を公開実験した（2006 年 6 月 25 日）。溶質 [酸 化アルミニウム $0.151 \mathrm{~g}+$ 酸化クロム $\left.\left(\mathrm{Cr}_{2} \mathrm{O}_{3}\right) 0.005 \mathrm{~g}\right]$ とフラ ックス [酸化モリブデン $2.825 \mathrm{~g}$ 十炭酸ナトリウム $\left(\mathrm{Na}_{2} \mathrm{CO}_{3}\right)$ $0.042 \mathrm{~g}$ ] の各粉末試薬を混合した調合物（約 $3 \mathrm{~g}$ ）を作った. それを白金るつぼ（容量 $30 \mathrm{~cm}^{3}$ ) に充填し，ふたをした。 そ のるつぼを市販の電気炬に入れ，約 55 分間で $1100^{\circ} \mathrm{C}$ ま加 熱し, 約 125 分間保持した。電気炉の電源を切り, 室温まで 放冷し，電気炉からるつぼを取りだした。晶出状況を観察し ながら，成長した結晶を採取した．結晶の色相や形態を観察 した.

電気炉で高温を得るために，滝用水車からの電力（交流） を直流に変換してから 12 個（電圧 : $12 \mathrm{~V}$, 容量 : $28 \mathrm{Ah}$ ）の バッテリーに蓄えた. その直流を再び交流に変換して電気炉 に使用した。

\section{3. 実験結果}

3-1 予備実験＼cjkstart酸化モリブデンを基本とするフラックス を $1100^{\circ} \mathrm{Cで}$ 蒸発させると, 目的のルビー単結晶が成長するこ とを確認した. 調合物量は約 $3 \mathrm{~g}$ が適切であった. 酸化モリ ブデンに酸化ナトリウムを添加したフラックスが高品質結 晶を育成するのに有効であった，最適の調合物は，2.に記し た化学組成であることを明らかにした．充電した 12 個のバ ッテリーは, 電気炉を $1100^{\circ} \mathrm{C} に$ 加熱して, その温度で $2 \sim 3$ 時 間保持する能力をもっていた。

3-2 公開実験 松井川に滝用水車を設置した。 その設置の 様子を Fig.1 に示す. 水車を用いて発電した電力は, 電気炉 を $1100^{\circ} \mathrm{C}$ まて加熱して 2 時間ほど保持するために十分であ った.

育成実験の終了後, 白金るつぼの壁面や底面に付着して成 長した赤色透明の単結晶（Fig.2）を確認した，その結晶がル ビーであることは，X線回折法や電子線マイクロアナライザ 一法によって同定した. 最大ルビー結晶のサイズは, 約 0.4 $\mathrm{mm}$ であった. 赤色の濃淡は, 着色剂である酸化ク口ムの添 加量によって変わった. ルビ一結晶は, フラットな二等辺三 角形の結晶面だけで囲まれた自形をもち, 光を反射してキラ ッと輝いた. その結晶面の指数は $\{11 \overline{2} 3\}$ であった. 結晶の形 態は, Fig.2 からも明らかなように, 六方両錐の十二面体を 基本としていた.

酸化モリブデンフラックスはほとんど蒸発したために, 結 


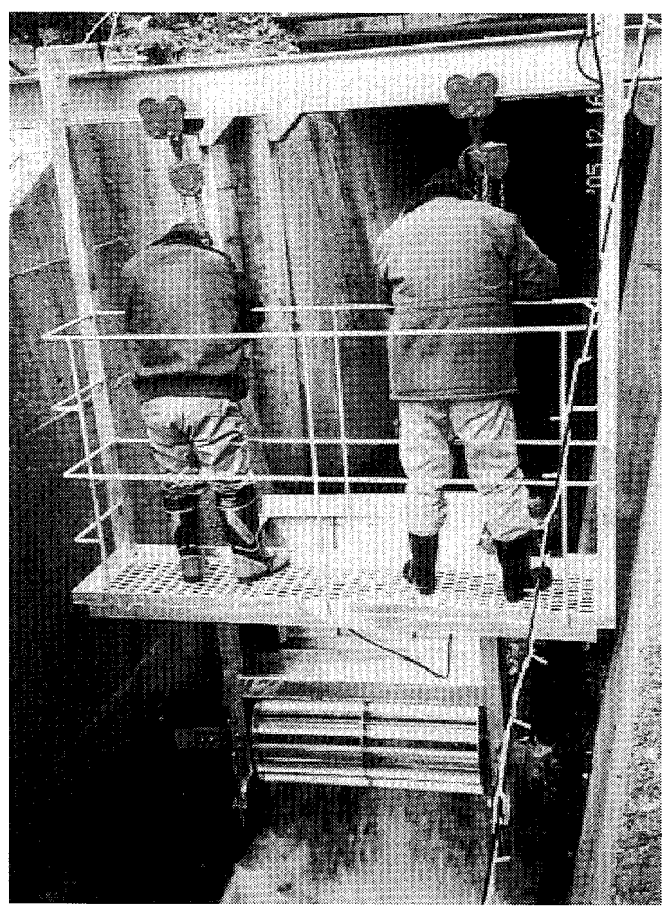

Fig.1 Setting of micro hydro turbine in waterfall

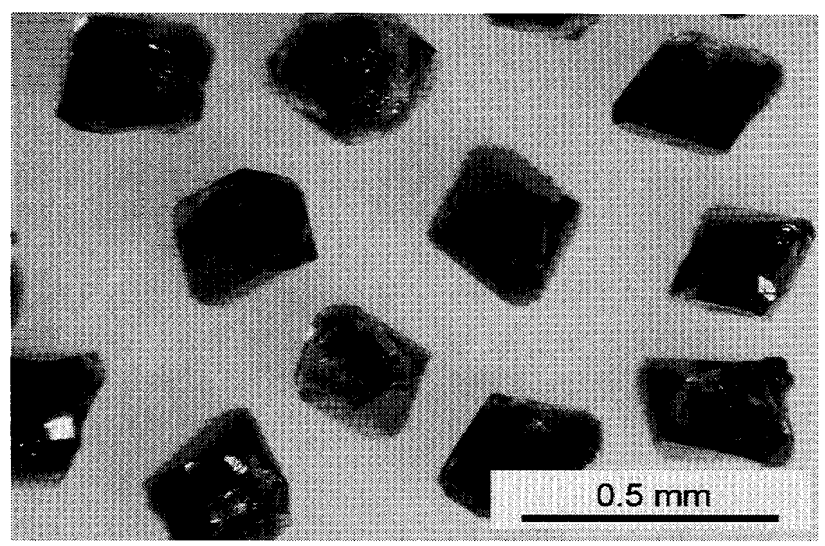

Fig.2 Ruby crystals grown from $\mathrm{MoO}_{3}$ flux

晶とフラックスの分離はきわめて容易であった. 結晶表面に わずかに付着したフラックスは，温水で溶解して除去した。 使用した白金るつぼの損傷はなかった. 比較的簡便な装置を 用い, 水車からの電力を用いて, 約 3 時間でルビ一結晶を作 ることができた. 身近な小川の小さな滝の流れに置いた水車 で得た電力は，高温 $\left(1100^{\circ} \mathrm{C}\right)$ においてルビー結晶を育成す る実験を行うために十分であった.

酸化モリブデン系をフラックスとする結晶育成技術の確 立により，宝石の代表であるルビ一結晶を容易に作ることが できるようになった ${ }^{8)}$.ルビー結晶作りの装置は簡便であり， 操作はやさしい。宝石はあこがれの物質であり，「宝石作り」 は昔から多くの人たちがチャレンジしてきた分野である. 「水車発電」と「ルビー結晶育成」の両技術が組み合わさり, 「水車でルビーを!」が実現した. 流体工学（機械工学）と 無機材料化学 (物質工学) の両分野の共同実験であった. 本 公開実験は，老若男女に興味をもたれ，新聞，テレビなどで も広く報道された.「水車」と「ルビー」の組み合わせにも 意外性があった.

今回，調合物量をきわめて小さくせざるを得ないために， 成長したルビー結晶の最大サイズは約 $0.4 \mathrm{~mm}$ であった。今 後, $\mathrm{mm}$ サイズの大きなルビ一結晶を作るためには, 発電量
を増加させるためのシステム改良と結晶育成条件の工夫が 必要である。

\section{4. おわりに}

身近な川の小さな滝の流れからマイクロ水力発電した電 力を利用して，わずか 3 時間ほどでルビー結晶作りができる ことがわかった，低い環境負荷で発電した電力を利用し，環 境負荷の低い条件下（温度, 試薬, 装置, 操作など）におい て，希少で高価な赤色透明のルビ一結晶（最大約 $0.4 \mathrm{~mm}$ ) を育成した，結晶は，明瞭な自形をもち，きわめて高品質で あった。自然のエネルギーを利用し，地球に代わってのルビ 一作りである.

\section{謝辞}

本研究の遂行にあたり，エコロジー・エネルギー研究会な らびに小諸市にご協力いただいた。記して謝意を表する。

\section{文献}

(1) S. Oishi, K. Teshima, H. Kondo, J. Am. Chem. Soc., 126, 4768 (2004).

(2) K. Teshima, H. Kondo, S. Oishi, J. Gemm., 29, 450 (2005).

(3) K. Teshima, A. Takano, T. Suzuki, S. Oishi, Chem. Lett., 34, 1620 (2005).

(4) 手嶋勝弥, 近藤人資, 鈴木孝臣, 大石修治, J. Ceram. Soc. Japan, 113, 733 (2005).

(5) K. Teshima, H. Kondo, S. Oishi, Bull. Chem. Soc. Jpn., 78, 1259 (2005).

(6) 手嶋勝弥，宮島章子，近藤人資，望月圭介，鈴木孝臣, 大石修治, J. Ceram. Soc. Japan, 113, 758 (2005).

(7) 池田敏彦，長澤忠延，“環境と技術一経済との調和を目 指して”，小林光征，藤井恒男編，信濃毎日新聞社，(2004） pp. $152 \sim 164$.

(8) 大石修治, 手嶋勝弥, 宮本 亮, 宮坂 晃, 鈴木孝臣, 化 学と教育, 54, 356 (2006). 